Butwal Campus Journal, Vol. 3, No. 1: 21-36, July 2020

Research Management Cell, Butwal Multiple Campus, Tribhuvan University, Nepal

\title{
PERFORMANCE ASSESSMENT OF NEPALESE BANKS BASED ON LEARNING AND GROWTH PERSPECTIVE
}

\author{
Dilip Parajuli* \\ *Associate Professor, Bhaktapur Multiple Campus, Bhaktapur, TU
}

Article History: Received 7 May 2020; Reviewed 30 May 2020; Revised 24 June 2020; Accepted 06 July 2020

\begin{abstract}
The purpose of this paper is to assess performance of Nepalese banks under the learning and growth perspective of the BSC model and to study comparative status of learning and growth in three types of banks - the state owned, private and joint venture banks. This paper follows a descriptive research design approach. The questionnaire survey has been applied as primary tool for collecting required information and 466 responses were collected from bank managers. To assess the responses to the BSC model's learning and growth perspective, a five-point Likert-type scale of strongly disagree (1) to strongly agree (5) has been used. The findings of study have indicated that joint venture banks stood at top, state owned banks in second and private banks in the bottom to adopt learning and growth perspective performance. The descriptive analysis has shown satisfactory status of the banks. Among the fourteen items used for assessment of learning and growth performance, improving employee capabilities, teamwork, and better culture and leadership were more emphasized areas by the banks to enhance learning and growth performance.
\end{abstract}

Keywords: banking industry - balanced scorecard - growth perspective- learning - managers

\section{INTRODUCTION}

The banking industry is a very important service sector in every economy and can promote efficiency and creativity in the economy when it is competitive and efficient (Falkena et al., 2004). In Nepal, this industry has been competing in terms of price, quality levels, 
advertisement, creativity in goods and services provided in relationship management, and product differentiation to win the customer over others. In such a reality, it is assumed that the Nepalese commercial banks have to use the balanced scorecard (BSC) model to measure their performance whether they are able or not to compete in the competitive environment.

The notion of the balanced scorecard (BSC) was first implemented in the early 1990s (Theuri \& Mugambi, 2014). Particularly, in 1992, Kaplan and Norton founded the BSC model on the premise that relying solely on financial results to measure the performance of the company and the importance of focusing on financial performance factors is not appropriate (Kaplan \& Norton, 1992). The BSC model has been identified as a value-creation framework and mechanism (Zhang, 2016; Kaplan \& Norton, 2001, 2004; Bryant, Jones, \& Widener, 2004). The BSC model translates the vision of companies into everyday activities and allows management strategy to be matched with the goals of the business (Zhang, 2016). The BSC is therefore assumed to lead organizations to generate and retain their competitive advantage. In order to assess whether the organization achieves common strategic objectives from four viewpoints, the BSC uses both financial and non-financial indicators, based on the key results: learning and growth, internal business processes, consumer and financial (Kaplan \& Norton, 2001). Each perspective of the BSC model specifies strategic goals that can offer the business a competitive advantage (Szóka, 2012). Out of them the learning and growth perspective are one of the key aspects of the BSC model.

Under the BSC model, the perspective of learning and growth refers to building organizational capacity through trained, qualified employees and peer services; developing and enabling employees to provide technology-based, high-quality, evidence-based, and culturally competent services and efficient and effective organizational design; preparing for future needs (Theuri \& Mugambi, 2014). In order to create long-term development and progress, this perspective outlines the infrastructure that the company must develop (Rillo, 2000). Rillo (2000) further added that three key sources of organizational learning and development come from people, systems, and organizational procedures. Businesses are expected to invest in re-skilling personnel, upgrading information infrastructure and processes, and aligning operational practices and routines. Intense global competition also allows businesses to continuously enhance their ability to offer value to consumers and shareholders. Usually, the financial, consumer, and internal business process goals of the BSC would expose wide differences between people's current skills, processes, and procedures and what will be needed to achieve breakthrough success goals. Companies would have to invest in re-skilling 
personnel, upgrading information infrastructure and systems, and aligning organizational processes and routines in order to close these gaps. In the BSC model's learning and growth perspective, these goals are articulated. So, to increase organizational performance, even commercial banks also need to concentrate on this perspective of the BSC model. It justifies the significance of the present study.

The learning and growth perspective serves as the foundation for any strategy. It describes the skills, abilities, and organizational climate of employees needed for businesses to adopt a strategy (Kaplan and Norton, 2001). In this regard, the purpose of this paper is to evaluate the condition of the learning and growth perspective of the BSC model concerning the Nepalese banking sector and to examine the comparative condition of this perspective in three bank classes (namely state-owned banks, private banks, and joint venture banks). The rest of this paper is organized as follows: section two presents review of related studies; section three describes research methodology; section four deals with study results and discussion; and section five concludes the study.

\section{LITERATURE REVIEW}

The movement towards the adoption of a balanced scorecard (BSC) as a set of performance measures is growing (Zelman, Pink \& Matthias, 2003). The feasibility and usefulness of using a balanced scorecard to assess success were illustrated in the literature (Chan \& Ho, 2000). In the face of organizational change, the need to remain competitive, profitable, and open to the challenges of the future is becoming more critical than ever and the demand for new technologies and services in today's context is just one of the challenges facing businesses today (Kaplan \& Norton 1996). In this context, the importance of the learning and growth perspective of the BSC model is on the rise. The BSC model's learning and growth perspective include research and development, the morale of workers, feedback from staff, etc (Rafiq et al., 2020). A need to recognize the multi-faceted concept of learning and growth to satisfy the ever-demanding need for organizational success was stated by Ferreira and Otley (2009).

Learning and growth perspective is necessary to acquire new talents, increase the capacity of information systems, motivation, authorization, and adaptation (Erdoğan, Onay, \& Karamaşa, 2019). Pourmoradi, Niknafs, and Abdollahian (2016) argued that as the most fundamental part of the BSC model, the learning and growth perspective focuses on how 
employees can develop themselves and create more value for the organization. GonzalezSanchez et al. (2017) mentioned that there is no doubt that perspectives of learning and growth, such as process efficiency (quality information system), employee ability (experienced and qualified), and the degree of business cohesion (culture, teamwork, and congruence), play an important role in achieving the company's objectives. In fact, this view is closely linked to the sustainability problem of the company, which can be calculated in terms of employee engagement, employee empowerment, staff retention, turnover, and capacity for information technology (Al-Najjar \& Kalaf, 2012; Hasan \& Chyi, 2017).

In the Nepalese context, a few recent studies (e.g., Parajuli, 2017, Parajuli \& Shrestha, 2020a; Parajuli \& Shrestha, 2020b) have been carried out locally on the BSC model. The application of the BSC approach to the implementation of strategy and performance management was presented in those studies. These studies have also shown that the BSC model has helped to enhance the performance of organizations. This paper, however, seeks to analyze the learning and growth perspective in Nepal's banking industry under the BSC model, and hence this study seeks to fill the knowledge gap.

\section{RESEARCH METHODS}

This paper follows a descriptive design. The questionnaire survey is a basic research tool used to gather data from the perspective of learning and growth (an indicator of the BSC model). Three classes of banks are considered as study units, such as state-owned banks, private banks, and joint venture banks. There were a total of 1,015 questionnaires distributed among the managers of different branches of these banks. The specifics of the distributed questionnaire and its response rate are listed in Table 1.

Table 1: Responses from three bank classes

\begin{tabular}{lccc}
\hline Classes of banks & $\begin{array}{c}\text { No. of } \\
\text { questionnaire } \\
\text { distributed }\end{array}$ & $\begin{array}{c}\text { No. of responses } \\
\text { received }\end{array}$ & $\begin{array}{c}\text { Response rate } \\
\text { (In percentage) }\end{array}$ \\
\hline State owned banks & 105 & 78 & 74.29 \\
Private banks & 735 & 278 & 37.82 \\
Joint venture banks & 175 & 110 & 62.86 \\
\hline Total & 1015 & 466 & 46 \\
\hline Source: Questionnaire survey, 2020 & & &
\end{tabular}


To assess the responses to the BSC model's learning and growth perspective, a fivepoint Likert-type scale from strongly disagree (1) to strongly agree (5) was used. Based on different literature sources, this paper applied 14 items such as employee capabilities, employee satisfaction, training and development schemes, the morale of the employee, productivity of the employee, employee's absenteeism, employee's turnover, market share, service sales from new products, better technology adoption, information technology, employee's empowerment, teamwork, culture, and leadership to evaluate the overall condition of the leaning and growth perspective of the banking industry of Nepal.

\section{STUDY RESULTS AND DISCUSSION}

This section presents the results of the data analysis and findings of the condition of the learning and growth perspective of the BSC model in the Nepalese banking industry and the comparative condition of this perspective in three bank classes.

\section{Comparative status of learning and growth perspective as per bank type}

\section{Employee capabilities}

Employee capabilities are the outcomes of regular learning. They can grow their capacity and skills through continuous learning. To know the status of improvement of employee capabilities, this item was included in the survey. The following result has been obtained and tabulated in Table 2.

Table 2: Employee capabilities

\begin{tabular}{lcccccc}
\hline \multicolumn{1}{c}{ Bank Classes } & $\begin{array}{c}\text { Strongly } \\
\text { Disagree }\end{array}$ & Disagree & Undecided & Agree & $\begin{array}{c}\text { Strongly } \\
\text { Agree }\end{array}$ & \\
& 1 & 2 & 7 & 54 & 14 & 78 \\
State owned banks & 1 & 11 & 32 & 181 & 53 & 278 \\
Private banks & 0 & 2 & 19 & 70 & 19 & 110 \\
Joint venture banks & 2 & 15 & 58 & 305 & 86 & 466 \\
\hline Total & & & & &
\end{tabular}

Source: Author's calculation 
According to the result, the state-owned banks have emphasized more in enhancement of employee capabilities. The private banks are moderate and the joint venture banks have lowest score in employee capabilities development programs.

\section{Employee satisfaction}

An organization with more employee satisfaction can have better learning and growth. Table 3 indicates managers' opinions about the level of their employee satisfaction.

Table 3: Employee satisfaction

\begin{tabular}{lcccccc}
\hline \multicolumn{1}{c}{ Bank Classes } & $\begin{array}{c}\text { Strongly } \\
\text { Disagree }\end{array}$ & Disagree & Undecided & Agree & $\begin{array}{c}\text { Strongly } \\
\text { Agree }\end{array}$ & Total \\
\hline State owned banks & 0 & 7 & 21 & 44 & 6 & 78 \\
Private banks & 16 & 52 & 86 & 105 & 19 & 278 \\
Joint venture banks & 1 & 12 & 31 & 57 & 9 & 110 \\
\hline Total & 17 & 71 & 138 & 206 & 34 & 466 \\
\hline
\end{tabular}

Source: Author's calculation

Employee satisfaction is found highest in state owned banks and lowest in joint venture banks. For employee satisfaction, the state-owned bank has provided more facilities as to satisfy employees.

\section{Training and development schemes}

For better learning and growth in skills of the employees, organizations offer different types of training and development programs. The respondents' replies to their banks' employee development schemes are in Table 4.

Table 4: Training and development schemes

\begin{tabular}{lcccccc}
\hline \multicolumn{1}{c}{ Bank Classes } & $\begin{array}{c}\text { Strongly } \\
\text { Disagree }\end{array}$ & Disagree & Undecided & Agree & $\begin{array}{c}\text { Strongly } \\
\text { Agree }\end{array}$ & Total \\
& 3 & 10 & 20 & 32 & 13 & 78 \\
\hline State owned banks & 17 & 50 & 73 & 115 & 23 & 278 \\
Private banks & 2 & 13 & 29 & 54 & 12 & 110 \\
Joint venture banks & 22 & 73 & 122 & 201 & 48 & 466 \\
\hline Total & & & & &
\end{tabular}

Source: Author's calculation 
The result has shown that joint venture banks have provided more training and development opportunities to their employees and the state-owned banks came in second position. However private banks found to be at bottom in training and development area.

\section{Morale of employee}

Employee morale is the basic determinants to better learning and growth. The statement - higher morale of our employee -has been rated by the managers in Table 5 .

Table 5: Morale of employee

\begin{tabular}{lcccccc}
\hline \multicolumn{1}{c}{ Bank Classes } & $\begin{array}{c}\text { Strongly } \\
\text { Disagree }\end{array}$ & Disagree & Undecided & Agree & $\begin{array}{c}\text { Strongly } \\
\text { Agree }\end{array}$ & Total \\
\hline State owned banks & 1 & 6 & 17 & 45 & 9 & 78 \\
Private banks & 12 & 38 & 81 & 120 & 27 & 278 \\
Joint venture banks & 2 & 7 & 32 & 55 & 14 & 110 \\
\hline Total & 15 & 51 & 130 & 220 & 50 & 466 \\
\hline
\end{tabular}

Source: Author's calculation

According to the result, employee morale was found highest in state owned banks, moderate in joint venture banks and lowest in private banks of Nepal.

\section{Productivity of employee}

Higher employee productivity is the outcome of continuous learning. To evaluate the level of employee productivity the statement - Higher employee productivity -was presented for rating. The result in Table 6 indicates the respondents' opinions.

Table 6: Employee productivity

\begin{tabular}{lcccccc}
\hline \multicolumn{1}{c}{ Bank Classes } & $\begin{array}{c}\text { Strongly } \\
\text { Disagree }\end{array}$ & Disagree & Undecided & Agree & $\begin{array}{c}\text { Strongly } \\
\text { Agree }\end{array}$ & Total \\
\hline State owned banks & 2 & 18 & 23 & 32 & 3 & 78 \\
Private banks & 3 & 17 & 73 & 146 & 39 & 278 \\
Joint venture banks & 0 & 3 & 31 & 60 & 16 & 110 \\
\hline Total & 5 & 38 & 127 & 238 & 58 & 466 \\
\hline
\end{tabular}

Source: Author's calculation 
The other dimension in measuring learning and growth perspective- productivity of employee found to be highest in joint venture banks, private banks at second position and lowest in state owned banks.

\section{Employee's absenteeism}

Less absenteeism of employees is a positive sign for organizational betterment. Table 7 reports the views of respondents about less employee absenteeism in their banks.

Table 7: Less employee absenteeism

\begin{tabular}{lcccccc}
\hline \multicolumn{1}{c}{ Bank Classes } & $\begin{array}{c}\text { Strongly } \\
\text { Disagree }\end{array}$ & Disagree & Undecided & Agree & $\begin{array}{c}\text { Strongly } \\
\text { Agree }\end{array}$ & Total \\
\hline State owned banks & 2 & 12 & 16 & 43 & 5 & 78 \\
Private banks & 0 & 30 & 71 & 145 & 32 & 278 \\
Joint venture banks & 0 & 7 & 23 & 68 & 12 & 110 \\
\hline Total & 2 & 49 & 110 & 256 & 49 & 466 \\
\hline Source: Author's calculation & & & & & &
\end{tabular}

The result has reported that employee absenteeism was found lowest in joint venture banks, moderate in private banks and highest in state owned banks.

\section{Employee's turnover}

The higher employee turnover is a symbol of an unstable workforce. The respondents have replied to the statement- less employee turnover rate. The results are reported in Table 8.

Table 8: Higher employee turnover

\begin{tabular}{lcccccc}
\hline \multicolumn{1}{c}{ Type of the banks } & $\begin{array}{c}\text { Strongly } \\
\text { Disagree }\end{array}$ & Disagree & Undecided & Agree & $\begin{array}{c}\text { Strongly } \\
\text { Agree }\end{array}$ & Total \\
& 2 & 11 & 17 & 39 & 9 & 78 \\
State owned banks & 8 & 71 & 89 & 88 & 22 & 278 \\
Private banks & 0 & 7 & 30 & 55 & 18 & 110 \\
Joint venture banks & 10 & 89 & 136 & 182 & 49 & 466 \\
\hline Total & & & & & &
\end{tabular}

Source: Author's calculation 
Employee turnover rate was found highest in joint venture bank and state-owned banks have moderate turnover. The private banks have lowest turnover rate in comparison with public and joint venture banks.

\section{Market share}

The growth of market share indicates success. Therefore, companies deserve a satisfactory market growth rate. Table 9 shows managers' opinions about the satisfactory growth rate of their banks' market shares.

Table 9: Market share

\begin{tabular}{lcccccc}
\hline \multicolumn{1}{c}{ Bank Classes } & $\begin{array}{c}\text { Strongly } \\
\text { Disagree }\end{array}$ & Disagree & Undecided & Agree & $\begin{array}{c}\text { Strongly } \\
\text { Agree }\end{array}$ & Total \\
\hline State owned banks & 0 & 9 & 12 & 52 & 5 & 78 \\
Private banks & 4 & 30 & 70 & 151 & 23 & 278 \\
Joint venture banks & 2 & 4 & 17 & 74 & 13 & 110 \\
\hline Total & 6 & 43 & 99 & 277 & 41 & 466 \\
\hline Source: Author's calculation & & & & & &
\end{tabular}

The result indicated that growth of market share was found highest in joint venture banks. The state-owned banks have second position and private banks relatively have lowest growth rate.

\section{Service sales from new products}

The significant percentage of service sales from new products indicates the company's performance in terms of growth. The statement - the significant percentage of service sales from new products - has been replied by the managers as in Table 10.

Table 10: Service sales from new products

\begin{tabular}{lcccccc}
\hline Bank Classes & $\begin{array}{c}\text { Strongly } \\
\text { Disagree }\end{array}$ & Disagree & Undecided & Agree & $\begin{array}{c}\text { Strongly } \\
\text { Agree }\end{array}$ & \\
\hline State owned banks & 0 & 14 & 25 & 37 & 2 & 78 \\
Private banks & 0 & 30 & 100 & 127 & 21 & 278 \\
Joint venture banks & 1 & 11 & 34 & 59 & 5 & 110 \\
\hline Total & 1 & 55 & 159 & 223 & 28 & 466 \\
\hline
\end{tabular}

Source: Author's calculation 
As per the result, joint venture banks have highest rate of service sale from new products. Private banks have second rank in new product launches and state-owned banks are in bottom in this regards.

\section{Better technology adoption}

Timely adoption of better technology enhances learning and growth capacity as well as the overall performance of a company. Table 11 represents respondents' views about the adoption of better technology by their banks.

Table 11: Adoption of better technology

\begin{tabular}{lcccccc}
\hline \multicolumn{1}{c}{ Bank Classes } & $\begin{array}{c}\text { Strongly } \\
\text { Disagree }\end{array}$ & Disagree & Undecided & Agree & $\begin{array}{c}\text { Strongly } \\
\text { Agree }\end{array}$ & \\
\hline State owned banks & 0 & 8 & 14 & 44 & 12 & 78 \\
Private banks & 2 & 24 & 61 & 156 & 35 & 278 \\
Joint venture banks & 0 & 6 & 23 & 62 & 19 & 110 \\
\hline Total & 2 & 38 & 98 & 262 & 66 & 466 \\
\hline
\end{tabular}

Source: Author's calculation

The result indicates that joint venture banks are ranked in top for adapting better technologies. The state-owned banks fall at second rank and private banks seems to be poor in adopting better technologies.

\section{Information technology}

Information technology is one of the basic factors that improve the overall performance of the firms. The status of advanced information technology adopted by the banks has been presented in Table 12 .

Table 12: Information technology

\begin{tabular}{lcccccc}
\hline \multicolumn{1}{c}{ Bank Classes } & $\begin{array}{c}\text { Strongly } \\
\text { Disagree }\end{array}$ & Disagree & Undecided & Agree & $\begin{array}{c}\text { Strongly } \\
\text { Agree }\end{array}$ & Total \\
& 0 & 9 & 12 & 44 & 13 & 78 \\
\hline State owned banks & 2 & 41 & 61 & 133 & 41 & 278 \\
Private banks & 0 & 6 & 18 & 70 & 16 & 110 \\
Joint venture banks & 2 & 56 & 91 & 247 & 70 & 466 \\
\hline Total & & & & & &
\end{tabular}


The result indicates that joint venture banks are ranked in top for adapting advanced information technologies. The state-owned banks fall at second rank and private banks seems to be poor in adopting advanced information technologies.

\section{Employee's empowerment}

Employee empowerment is necessary for better learning and growth. The managers have rated the statement - more efforts on employee empowerment. The result has been presented in Table 13.

Table 13: Employee empowerment

\begin{tabular}{lcccccc}
\hline \multicolumn{1}{c}{ Bank Classes } & $\begin{array}{c}\text { Strongly } \\
\text { Disagree }\end{array}$ & Disagree & Undecided & Agree & $\begin{array}{c}\text { Strongly } \\
\text { Agree }\end{array}$ & Total \\
& 1 & 6 & 16 & 47 & 8 & 78 \\
State owned banks & 12 & 46 & 73 & 122 & 25 & 278 \\
Private banks & 3 & 7 & 29 & 63 & 8 & 110 \\
Joint venture banks & 16 & 59 & 118 & 232 & 41 & 466 \\
\hline Total & & & & & &
\end{tabular}

Source: Author's calculation

In case of employee empowerment, the state-owned banks are ranked at top, joint venture at second place and private banks at bottom place. the result has shown more empowerment schemes provided by the state-owned banks.

\section{Teamwork}

Teamwork and better coordination among the employees are the key factors for overall efficiency and growth of banks, the statement-emphasized on teamwork was included in the questionnaire survey. Table 14 reports responses to this statement from the managers on this statement.

Table 14: Teamwork

\begin{tabular}{lcccccc}
\hline \multicolumn{1}{c}{ Bank Classes } & $\begin{array}{c}\text { Strongly } \\
\text { Disagree }\end{array}$ & Disagree & Undecided & Agree & $\begin{array}{c}\text { Strongly } \\
\text { Agree }\end{array}$ & \\
\hline State owned banks & 0 & 6 & 12 & 53 & 7 & 78 \\
Private banks & 6 & 27 & 40 & 154 & 51 & 278 \\
Joint venture banks & 2 & 3 & 20 & 69 & 16 & 110 \\
\hline Total & 8 & 36 & 72 & 276 & 74 & 466 \\
\hline
\end{tabular}

Source: Author's calculation 
Similarly, in case of employee teamwork practice, the joint venture banks are ranked at top, state owned banks in second place and private banks at bottom place.

\section{Culture and leadership}

A better culture and leadership support continuous learning and growth of employees' skills and capabilities. Table 15 reflects the opinions of the managers on the statement - our bank has a better culture and leadership.

Table 15: Culture and leadership

\begin{tabular}{lcccccc}
\hline \multicolumn{1}{c}{ Type of the banks } & $\begin{array}{c}\text { Strongly } \\
\text { Disagree }\end{array}$ & Disagree & Undecided & Agree & $\begin{array}{c}\text { Strongly } \\
\text { Agree }\end{array}$ & Total \\
\hline State owned banks & 0 & 10 & 21 & 42 & 5 & 78 \\
Private banks & 12 & 34 & 43 & 138 & 51 & 278 \\
Joint venture banks & 0 & 6 & 17 & 72 & 15 & 110 \\
\hline Total & 12 & 50 & 81 & 252 & 71 & 466 \\
\hline Source: Author's calculation & & & & & &
\end{tabular}

The result has shown that better culture and leadership practice found better in joint venture banks, private banks stood in second rank. However, the state-owned banks seemed in bottom place in maintaining better culture and leadership.

\section{Descriptive analysis of the learning and growth of the banks}

The part of the paper presents the condition of the learning and growth perspective of the BSC model in the Nepalese banking industry based on descriptive statistics. Table 16 reports descriptive statistics of the items used to evaluate performance of the banks under learning and growth perspective.

The mean score of descriptive analysis of all 14 items applied to assess bank performance under the learning and growth perspective is 3.6045. The result has indicated that mean scores of all items are above 3 . It means the above average provisions made by the banks to boost learning and growth opportunities to their employees and Nepalese banks have satisfactory performance in this perspective.

Among the items used, 'employee capabilities of the bank are improving' has the higher mean value of 3.9828. It shows greater efforts of the banks in enhancing employee capabilities. In the same way, teamwork and better bank culture and leadership were more 
emphasized areas. In addition, relatively, more employee satisfaction, less employee turnover rate, and more training and development schemes fall under the least preferred items by the respondent.

Table 16: Descriptive statistics on learning and growth perspective

\begin{tabular}{lcc}
\hline \multicolumn{1}{c}{ Statements } & Mean & $\begin{array}{c}\text { Std. } \\
\text { Deviation }\end{array}$ \\
\hline Employee capabilities & & .69074 \\
Employee satisfaction & 3.9828 & .95005 \\
Training and development schemes & 3.3627 & 1.02072 \\
Higher morale of employee & 3.3863 & .93719 \\
Higher employee productivity & 3.5129 & .83867 \\
Less employee absenteeism & 3.6567 & .82250 \\
Less employee turnover rate & 3.6459 & .97743 \\
Satisfactory growth rate of market share & 3.3670 & .81608 \\
Significant percentage of service sales from new products & 3.6524 & .78732 \\
Emphasis in adoption of better technology & 3.4764 & .81136 \\
Having advanced Information technology & 3.7554 & .88176 \\
More efforts on employee empowerment & 3.7017 & .94161 \\
Emphasis on teamwork & 3.4785 & .85890 \\
Better culture and leadership & 3.7983 & .94386 \\
& 3.6867 & \\
\hline \multicolumn{1}{c}{ Group mean } & $\mathbf{3 . 6 0 4 5}$ & \\
\hline
\end{tabular}

Source: Author's calculation

\section{CONCLUSION}

Kaplan and Norton (2004) introduced the strategic perspective of organizational learning and growth into the company's BSC model. The BSC model is used to describe and communicate strategies, and to formulate them (Kaplan \& Norton, 2005; 2006). The aim is to match organizational performance with the strategy, and the implementation of the strategy is its scope (Olson \& Slater, 2002). As a key aspect of the BSC model, the learning and growth perspective enables companies to align the human resources with firm strategies in order to achieve desired objectives (Zhang, 2016). 
The results from comparative performance assess of learning and growth perspective has indicated that joint venture banks of Nepal have more learning and growth attempts than other bank types. Among fourteen items used to measure learning and growth status, the joint venture banks got high score in eleven of them. Similarly, the state-owned banks found to be second bank type in adoption of better learning and growth efforts having highest scores in four items of this dimension. However, the private banks got no highest rank in any of the items of learning and growth dimension hence got lowest rank among all.

The results of descriptive analysis have shown that learning and growth perspective of the banking sector of Nepal is satisfactory. The evidences have shown that learning and growth improve the capability of the employees. Similarly, Teamwork and better culture and leadership are also important for enhancing the learning and growth perspectives of the BSC model. Regarding the condition, this perspective is found to a moderate level and the overall condition seems to be satisfactory in the Nepalese banking industry.

\section{REFERENCES}

Al-Najjar, S.M., \& Kalaf, K.H. (2012). Designing a balanced scorecard to measure a bank's performance: A case study. International Journal of Business Administration, 3(4), 44-53.

Bryant, L., Jones, D. A., \& Widener, S. K. (2004). Managing value creation within the firm: An examination of multiple performance measures. Journal of Management Accounting Research, 16(1), 107-131.

Chan, Y.C., \& Ho, S.J. (2000). Performance measurement and the use of balanced scorecard in Canadian hospitals. Advances in Management Accounting, 19, 145-169.

Erdoğan, N.K., Onay, A., \& Karamaşa, C. (2019). Measuring the performance of retailer firms listed in BIST under the balanced scorecard perspective by using interval valued Pythagorean Fuzzy AHP based Pythagorean Fuzzy TODIM Methodology. The Journal of Operations Research, Statistics, Econometrics and Management Information Systems, 7(2), 333-350.

Falkena, H., Gabriel, D., Hawkins, P., Llewellyn, D., Luus, C., Masilela, E., Parr, G., Pienaar, J., \& Shaw, H. (2004). Competition in South African Banking: Task Group Report for National Treasury and the South African Reserve Bank. Pretoria.

Ferreira, A., \& Otley, D. (2009). The design and use of performance management systems: An extended framework for analysis. Management Accounting Research, 20(4), 263-282. 
Gonzalez-Sanchez, M.B., Broccardo, L., \& Martins Pires, A.M. (2017). The use and design of the BSC in the health care sector: A systematic literature review for Italy, Spain, and Portugal. The International Journal of Health Planning and Management, 33(1), 6-30.

Hasan, R.U., \& Chyi, T.M (2017). Practical application of balanced scorecard - A literature review. Journal of Strategy and Performance Management, 5(3), 87-103.

Kaplan R.S., \& Norton, D.P. (2006) How to implement a new strategy without disrupting your organization. Harvard Business Review 65(1), 100-109.

Kaplan, R. S., \& Norton, D. P. (1992). The balanced scorecard: Measures that drive performance. Harvard Business Review, 70(1), 71-79.

Kaplan, R. S., \& Norton, D. P. (1996). Using the balanced scorecard as a strategic management system. Harvard Business Review, 74(1), 75-85.

Kaplan, R. S., \& Norton, D. P. (2001). Transforming the balanced scorecard from performance measurement to strategic management: Part I. Accounting Horizons, 15(1), 87-104.

Kaplan, R. S., \& Norton, D. P. (2004). The strategy map: guide to aligning intangible assets. Strategy \& Leadership, 32(5), 10-17.

Kaplan, R.S, \& Norton, D.P. (2005). The office of strategy management. Harvard Business Review, 72-80.

Olson, E., \& Slater, S. (2002). The balanced scorecard, competitive strategy, and performance. Business Horizon, 11-16.

Parajuli, D. (2017). Performance evaluation of Nepalese commercial banks based on balance scorecard. Unpublished Ph.D. Thesis, Faculty of Management, Tribhuvan University, Nepal.

Parajuli, D., \& Shrestha, P. (2020a). The relationship between balanced scorecard evaluation approach and organizational performance of commercial banks of Nepal. Research Journal of Finance and Accounting, 11(18), 1-8.

Parajuli, D., \& Shrestha, P. (2020b). Impact of balance scorecard dimensions on bank performance: Evidence from Nepal. Research Journal of Finance and Accounting, 11(20), 7-15.

Pourmoradi, R., Niknafs, J., \& Abdollahian, F. (2016). A literature review on balanced scorecard: Quantification of the balanced scorecard. Applied Mathematics in Engineering, Management and Technology, 4(3), 133-142.

Rafiq, M., Zhang, X., Yuan, J., Naz, S, \& Maqbool, S. (2020). Impact of a balanced scorecard as a strategic management system tool to improve sustainable development: Measuring the mediation of organizational performance through PLS-Smart. Sustainability, 12(1365), 119.

Rillo, M. (2000). Overview of Construction and Implementation of Balanced Scorecard. Estonian Business School, University in Tallinn, Estonia. 
Szóka, K. (2012). The significance of the balanced scorecard financial perspective - Presented through the example of the AMOENA Medical Devices Trade and Provider Ltd. Journal of International Studies, 5(1), 84-94.

Theuri, F, \& Mugambi, F. (2014). Institutionalizing the balanced scorecard to enhance employee performance: Lessons from the cooperative bank of Kenya. International Academic Journal of Information Sciences and Project Management, 1(3), 122-134.

Zelman, W.N., Pink, G.H., \& Matthias, C.B. (2003). Use of the balanced scorecard in health care. Journal of Health Care Finance, 29(4), 1-16.

Zhang, J. (2016). Empirical evidence on the use of the balanced scorecard and innovation: Exploring the role of firm competences and performance consequences. The University of Toledo, USA. 